\title{
Integration Architecture Capability Case Model
}

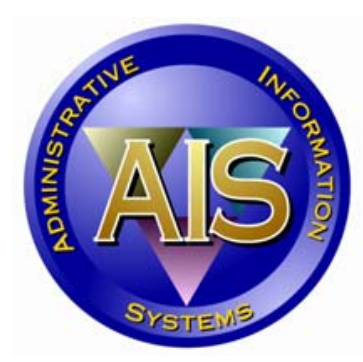

As of April 2004

Lawrence Livermore National Laboratory

Livermore, California 94550

UCRL-TR-203567 


\section{Disclaimer}

This document was prepared as an account of work sponsored by an agency of the United States Government. Neither the United States Government nor the University of California nor any of their employees, makes any warranty, express or implied, or assumes any legal liability or responsibility for the accuracy, completeness, or usefulness of any information, apparatus, product, or process disclosed, or represents that its use would not infringe privately owned rights. Reference herein to any specific commercial product, process, or service by trade name, trademark, manufacturer, or otherwise, does not necessarily constitute or imply its endorsement, recommendation, or favoring by the United States Government or the University of California. The views and opinions of authors expressed herein do not necessarily state or reflect those of the United States Government or the University of California, and shall not be used for advertising or product endorsement purposes. 


\section{Information Integration Architecture Capability Case Model}

- The LLNL Administrative Information Systems (AIS) Department is developing and refining strategies to address information and system integration.

- The "Framework for Integration of LLNL Business Operational Information" white paper authored by R. Watts (UCRL-AR-202823) identifies foundational principles for an information integration framework and provides a context for the Capability Case Model.

- AIS IT managers and staff are developing the Capabilities Case Model as a tool to identify the basic elements of an integration architecture. The model has been useful in clarifying integration approaches.

- This effort is a work in progress. The Capability Case Model is a working document and will be periodically revised, amended, and defined in greater detail as the architecture evolves.

- The Capability Case format was adopted with permission from Topquadrant, Inc. for LLNL internal use. 


\section{An information integration strategy and architecture will become foundational for all business domains}

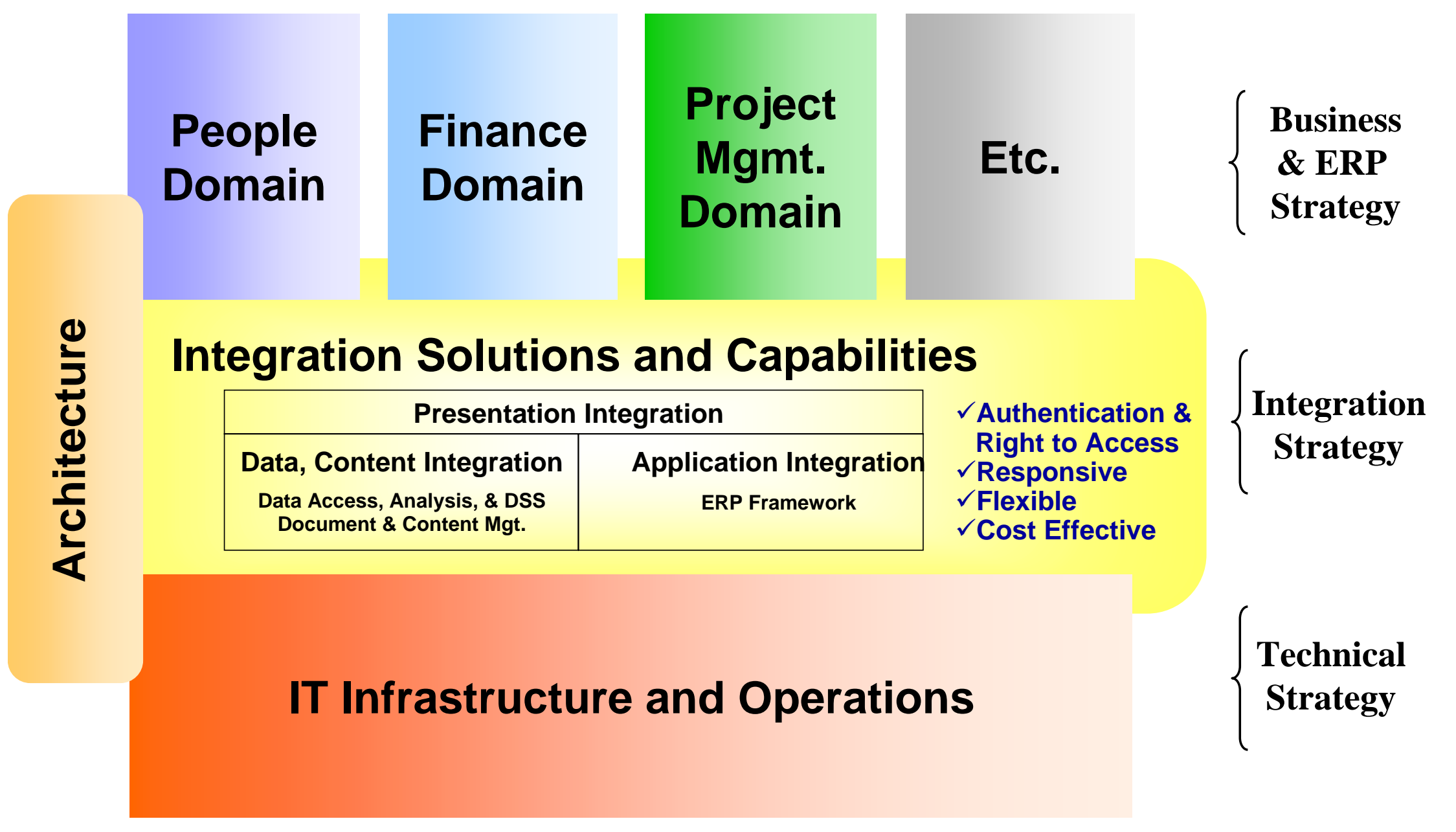




\section{A layered IT architectural is a key component of IT strategy}

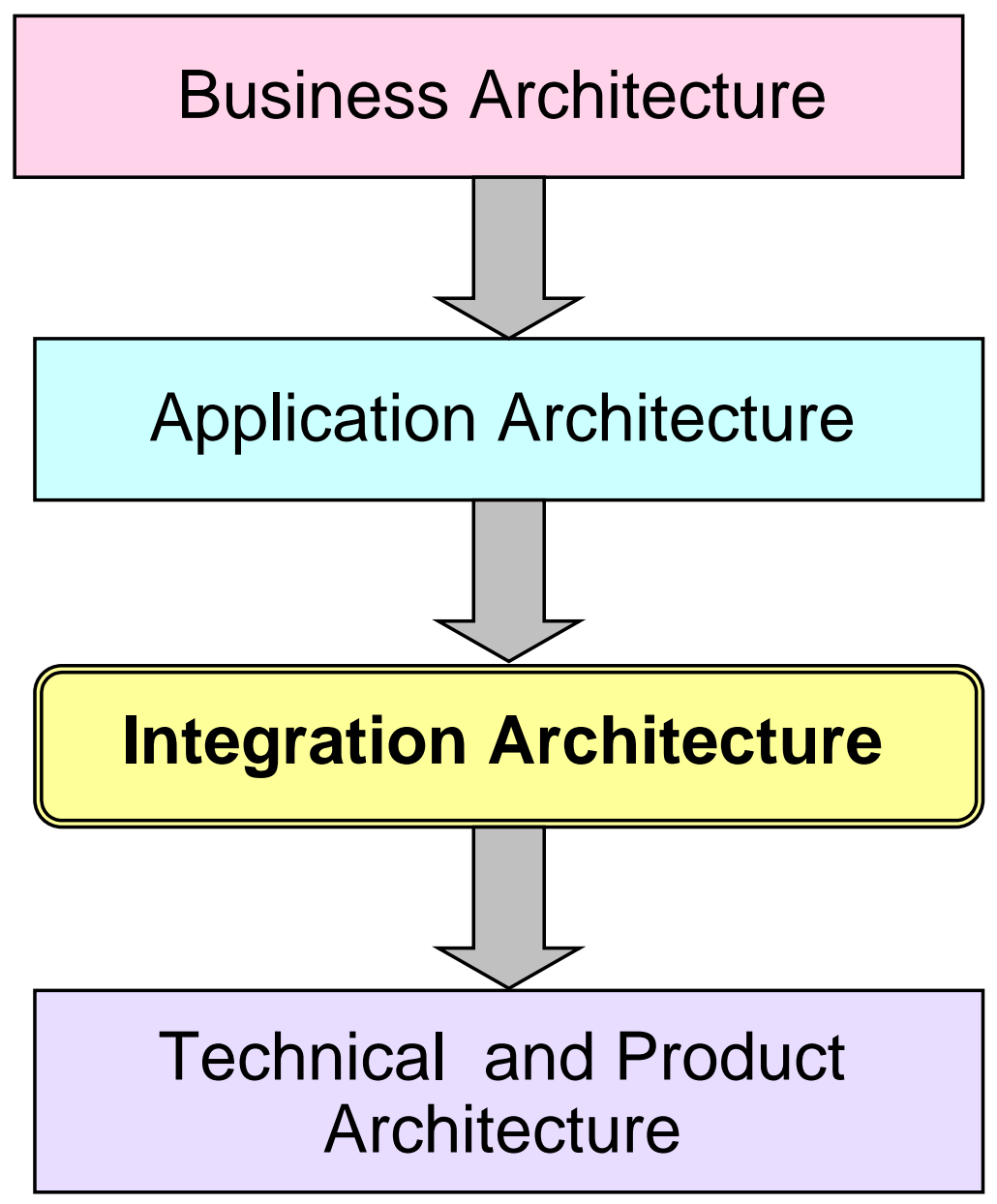

- An integration architecture is one layer in an over arching IT architectural strategy

- The integration architecture provides a basis for the integration of the various data, process, and presentation elements of the application architecture

- The integration and application architectures form the requirements for the technical and product architectures

- Conceptually, integration architecture requirements can be defined as is a set of capabilities and, at a high level, be described using a Capability Case format 


\section{Elements for information integration *}

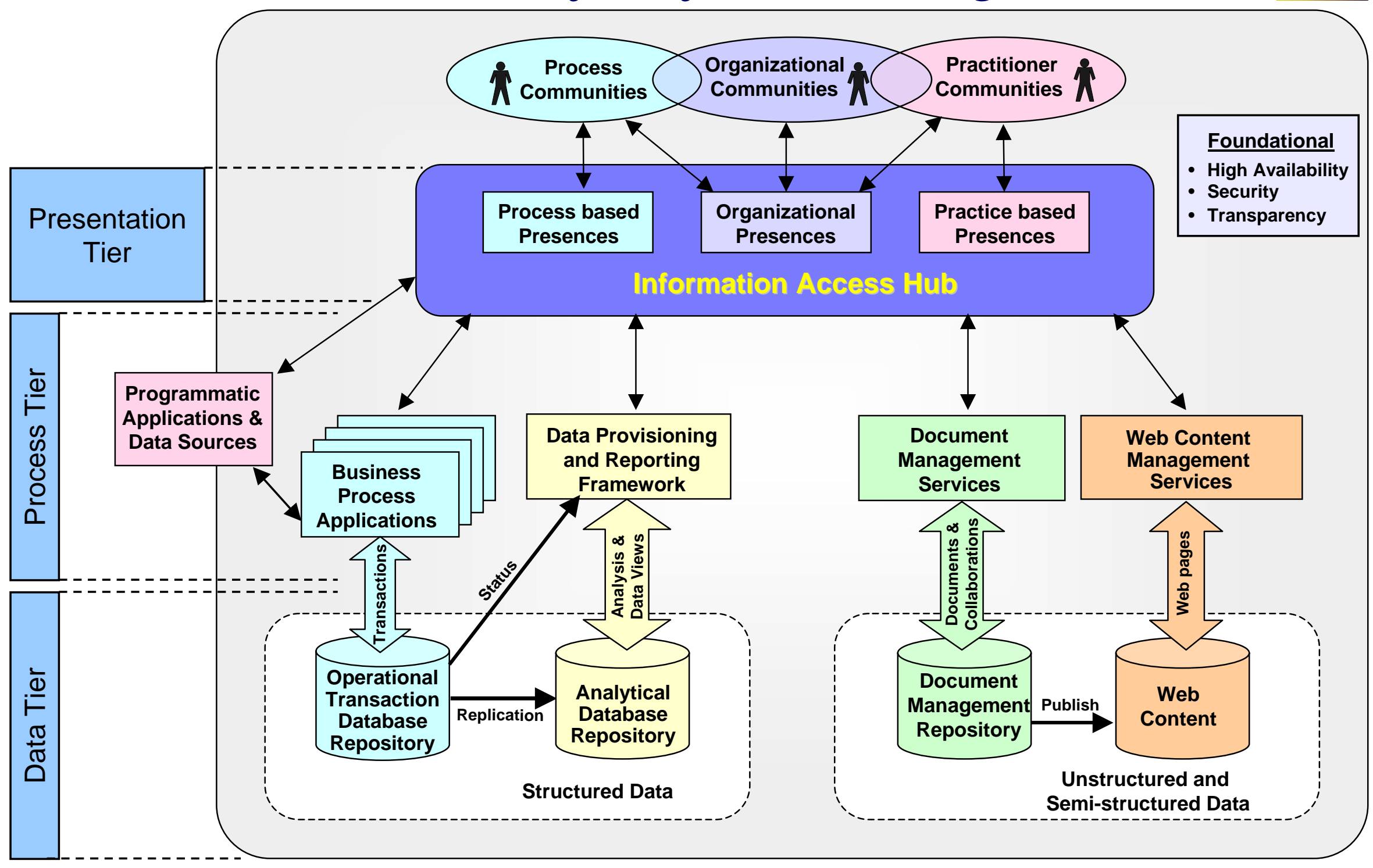

* Reference the "Framework for Integration of LLNL Business Operational Information" white paper by R. Watts (UCRL-AR-20823) 


\section{Integration Architecture Capability Matrix *}

\begin{tabular}{|c|c|c|c|c|c|c|c|}
\hline & & \multicolumn{5}{|c|}{ Business Architecture Pattern * } & \multirow{2}{*}{$\begin{array}{c}\text { Foundational } \\
\text { Capabilities }\end{array}$} \\
\hline & & $\begin{array}{l}\text { User to Business } \\
\text { (Transactional) }\end{array}$ & $\begin{array}{c}\text { User to Data } \\
\text { (Analytical) }\end{array}$ & $\begin{array}{l}\text { Bus. to Bus. } \\
\text { (Sys. to Sys.) }\end{array}$ & $\begin{array}{l}\text { User to User } \\
\text { (Interaction) }\end{array}$ & $\begin{array}{l}\text { Org. to User } \\
\text { (Informational) }\end{array}$ & \\
\hline \multicolumn{2}{|c|}{$\begin{array}{c}\text { Presentation } \\
\text { Tier }\end{array}$} & - eWorkplace & - eWorkplace & & - eWorkplace & - eWorkplace & \multirow{3}{*}{$\begin{array}{l}\text { - Application Roles } \\
\text { and Authorization } \\
\text { - Application } \\
\text { Security } \\
\text { - Browser and HTML } \\
\text { based Webtop stds. }\end{array}$} \\
\hline \multirow{2}{*}{ 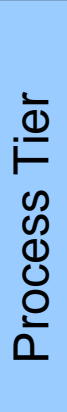 } & $\begin{array}{c}\text { Federated } \\
\text { (loose coupling) }\end{array}$ & $\begin{array}{l}\text { - Business Process } \\
\text { Orchestration } \\
\text { - Workflow }\end{array}$ & $\begin{array}{l}\text { - Enterprise Rptg. } \\
\text { - Decision Support } \\
\text { (static \& dynamic) }\end{array}$ & $\begin{array}{l}\text { - Synchronous } \\
\text { Request \& Reply } \\
\text { - Asynchronous } \\
\text { Publish \& } \\
\text { Subscribe }\end{array}$ & \multirow{2}{*}{$\begin{array}{l}\text { - Email } \\
\text { - Calendaring } \\
\text { - Document Mgt } \\
\text { - Distributed } \\
\text { Authoring and } \\
\text { Versioning } \\
\text { - Instant } \\
\text { Messaging } \\
\text { - On-line meeting } \\
\text { environments }\end{array}$} & \multirow[t]{2}{*}{$\begin{array}{l}\text { - Messaging } \\
\text { Facility }\end{array}$} & \\
\hline & \begin{tabular}{|c|} 
Monolithic \\
Homogenous \\
(tight coupling)
\end{tabular} & - Proprietary & $\begin{array}{l}\text { - Application Specific } \\
\text { Reporting }\end{array}$ & $\begin{array}{l}\text { - Inter-process } \\
\text { Communication } \\
\text { - File Transfer }\end{array}$ & & & \\
\hline \multirow{2}{*}{ 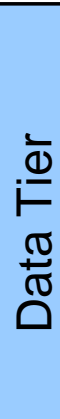 } & $\begin{array}{l}\text { Structured } \\
\text { (data) }\end{array}$ & $\begin{array}{l}\text { - Transactional } \\
\text { Relational } \\
\text { Database }\end{array}$ & $\begin{array}{l}\text { Data Repository } \\
\text { Architecture } \\
\text { ODS, EDD, } \\
\text { Data Mart }\end{array}$ & $\begin{array}{l}\text { Data Repository } \\
\text { Architecture } \\
\text { ODS, EDD, } \\
\text { Data Mart } \\
\text { - Extract, } \\
\text { Transform, Load } \\
\end{array}$ & & & \\
\hline & $\begin{array}{l}\text { Unstructured } \\
\text { (content) }\end{array}$ & - Document Mgt & $\begin{array}{l}\text { - Information Hubs } \\
\text { - Taxonomy } \\
\text { - Ontology/RDF } \\
\text { - ebXML }\end{array}$ & $\begin{array}{l}\text { - Files } \\
\text { - ebXML }\end{array}$ & $\begin{array}{l}\text { - Email Messages } \\
\text { - Document, Content } \\
\text { Repository }\end{array}$ & $\begin{array}{l}\text { - Messages } \\
\text { - Reference } \\
\text { Repository } \\
\text { (policies, etc.) }\end{array}$ & \\
\hline
\end{tabular}

* Reference the "Framework for Integration of LLNL Business Operational Information" white paper by R. Watts (UCRL-AR-20823) 


\section{Data Tier Capability Cases}

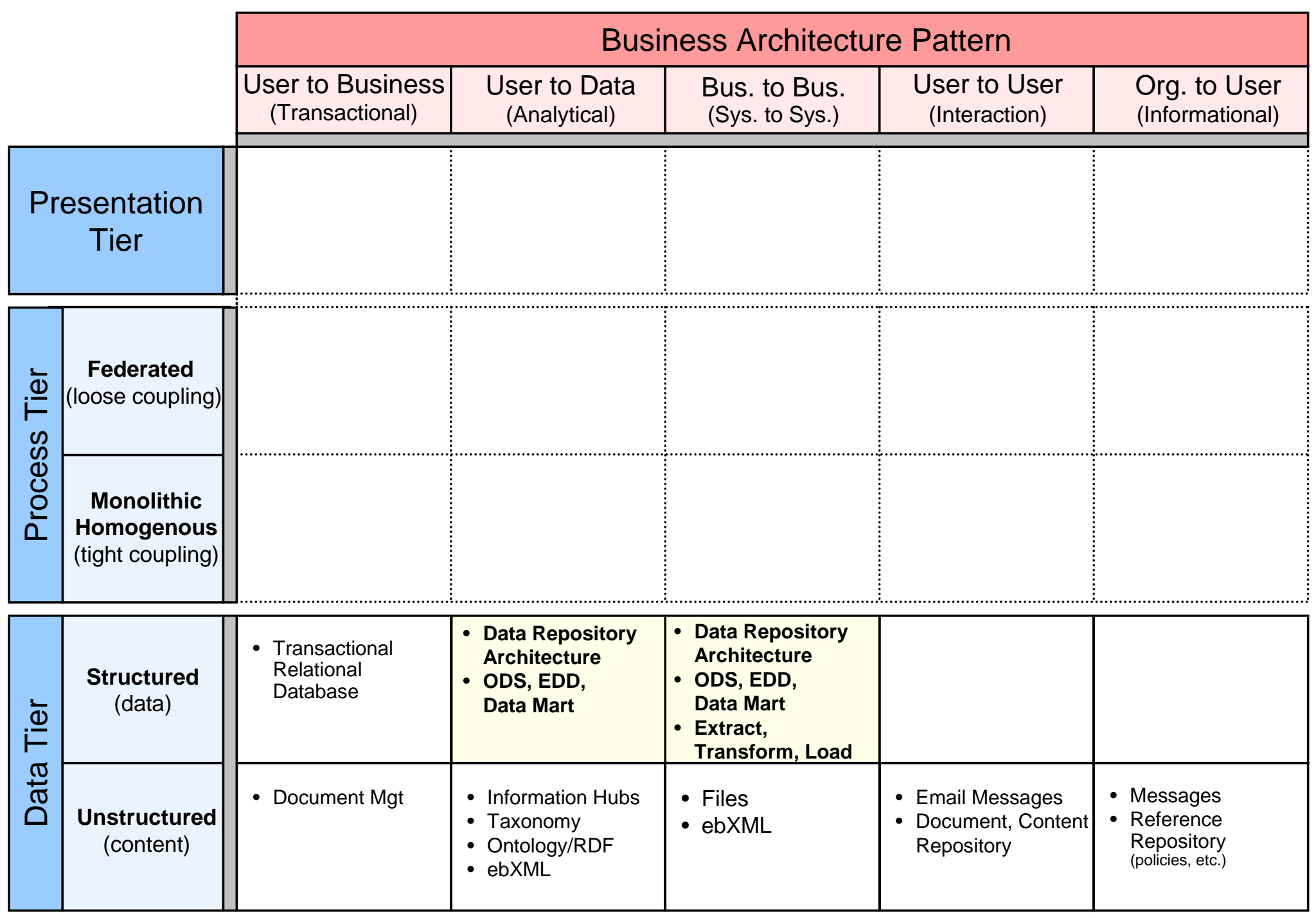




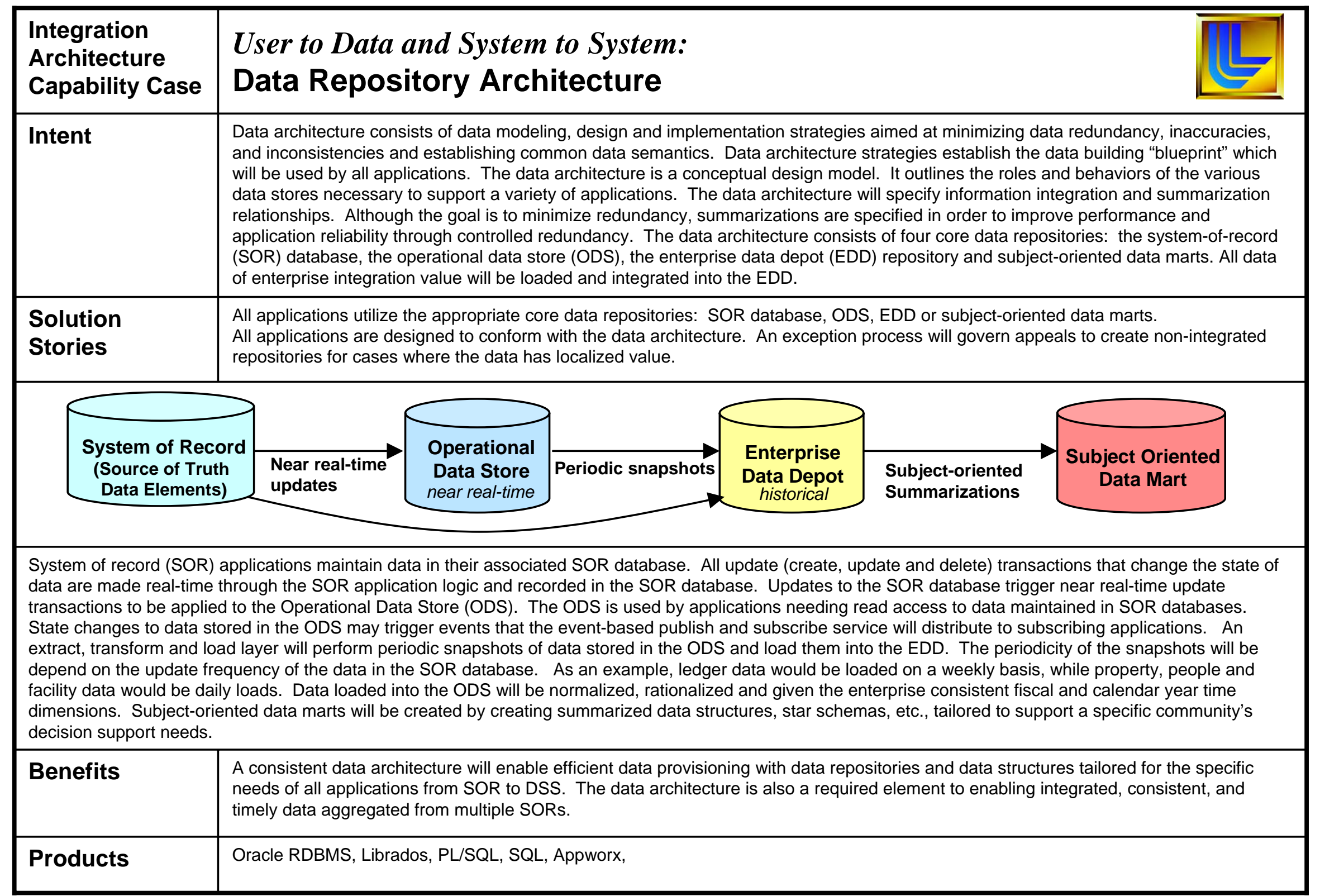

Note: Capability case diagrams reflect logical, not physical relationships.

As of $2 / 27 / 2004$ 


\begin{tabular}{|c|c|}
\hline $\begin{array}{l}\text { Integration } \\
\text { Architecture } \\
\text { Capability Case }\end{array}$ & $\begin{array}{l}\text { System to System: } \\
\text { Data Repository Architecture - Exception Case }\end{array}$ \\
\hline Intent & $\begin{array}{l}\text { This is an exception case to the enterprise data repository architecture for cases where the value of the data has been } \\
\text { determined to be localized in scope. Localization, means the data can be isolated (not integrated) because it provides no } \\
\text { potential enterprise data integration value. A governing board (to be determined) will rule on the enterprise integration value } \\
\text { of the data. If the data has been judged to have localized value, a Localized Data Mart (LDM) will be created to satisfy the } \\
\text { decision support system (DSS) needs of that work group. }\end{array}$ \\
\hline $\begin{array}{l}\text { Solution } \\
\text { Stories }\end{array}$ & $\begin{array}{l}\text { Work group members access a static or dynamic DSS application which utilizes a LDM which has been loaded via localized } \\
\text { summarization ETL processes which load data from the system of record (SOR) database. }\end{array}$ \\
\hline \multirow[b]{2}{*}{$\begin{array}{l}\text { System of Record } \\
\text { (Source of Truth } \\
\text { Data Elements) } \\
\end{array}$} & \\
\hline & \begin{tabular}{c|c|c|c}
$\begin{array}{c}\text { Operational } \\
\text { Data Store } \\
\text { near real-time }\end{array}$ & Periodic snapshots & $\begin{array}{c}\text { Enterprise } \\
\text { Data Depot } \\
\text { historical }\end{array}$ & $\begin{array}{c}\text { Subject-oriented } \\
\text { Summarizations }\end{array}$
\end{tabular} \\
\hline \multicolumn{2}{|c|}{$\begin{array}{l}\text { SOR applications maintain data in their associated SOR database. All update (create, update and delete) transactions that change the state of data } \\
\text { are made real-time through the SOR application logic and recorded in the SOR database. Periodic updates will build summarized data structures or } \\
\text { star schema tables to be used by a local DSS application. }\end{array}$} \\
\hline Benefits & $\begin{array}{l}\text { Extends the Enterprise Data Repository Architecture by providing support for data with localized value. This is an important } \\
\text { benefit as it enables the enterprise data model to remain simple and concise with only data with real enterprise integration } \\
\text { value or potential value. }\end{array}$ \\
\hline Products & Oracle RDBMS, Librados, PL/SQL, SQL, Appworx, \\
\hline
\end{tabular}

Note: Capability case diagrams reflect logical, not physical relationships. 


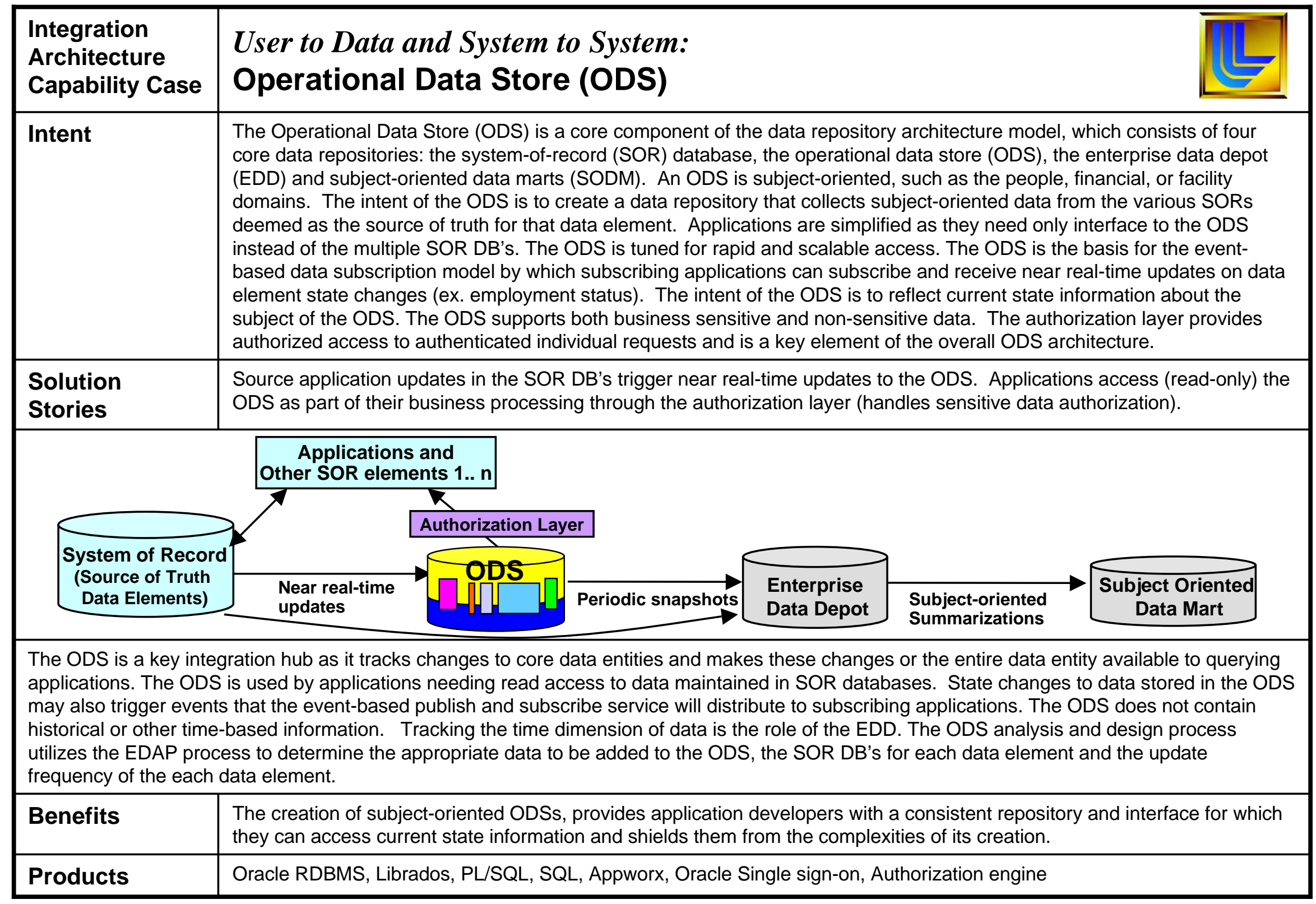

Note: Capability case diagrams reflect logical, not physical relationships. 


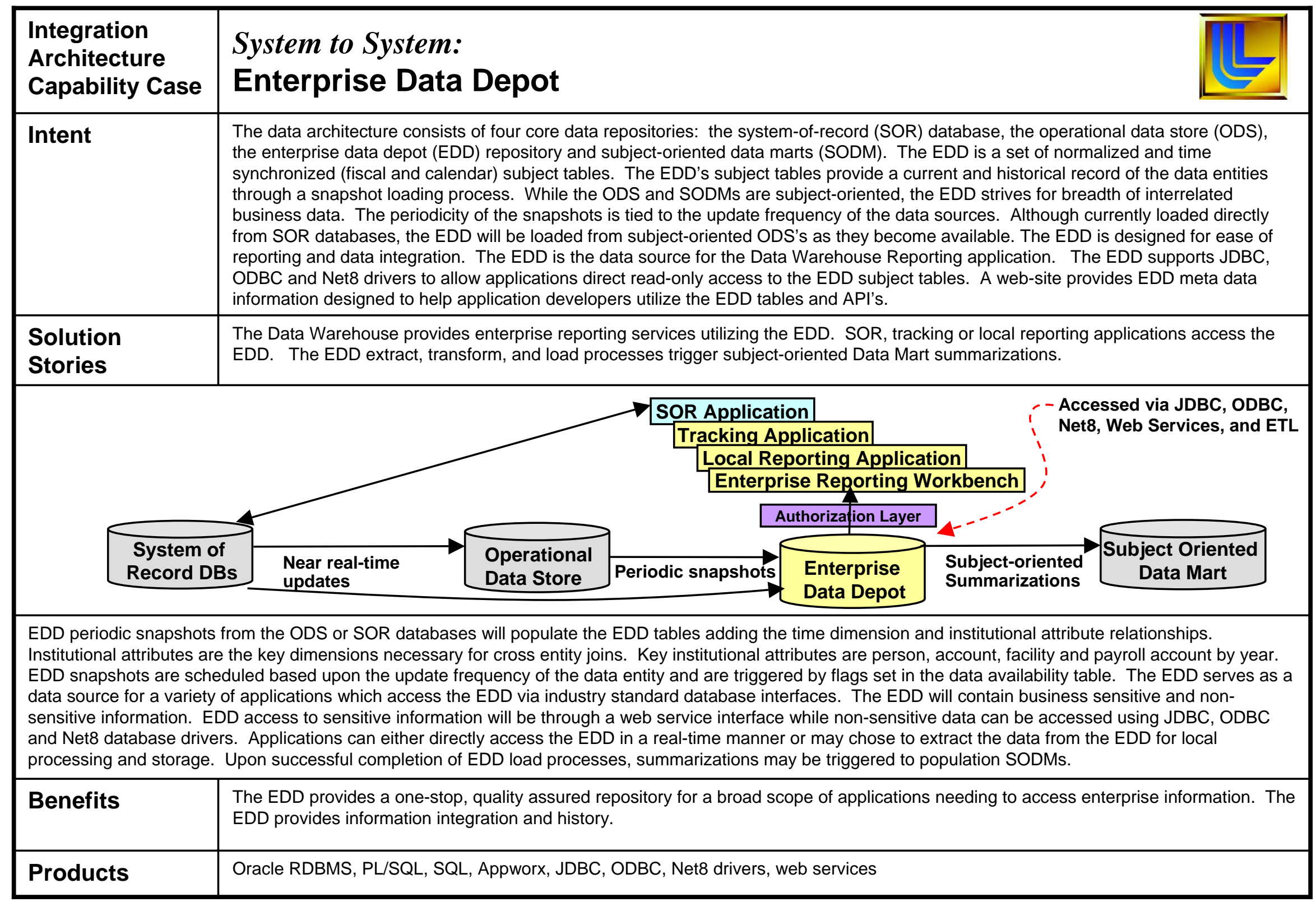

Note: Capability case diagrams reflect logical, not physical relationships. 


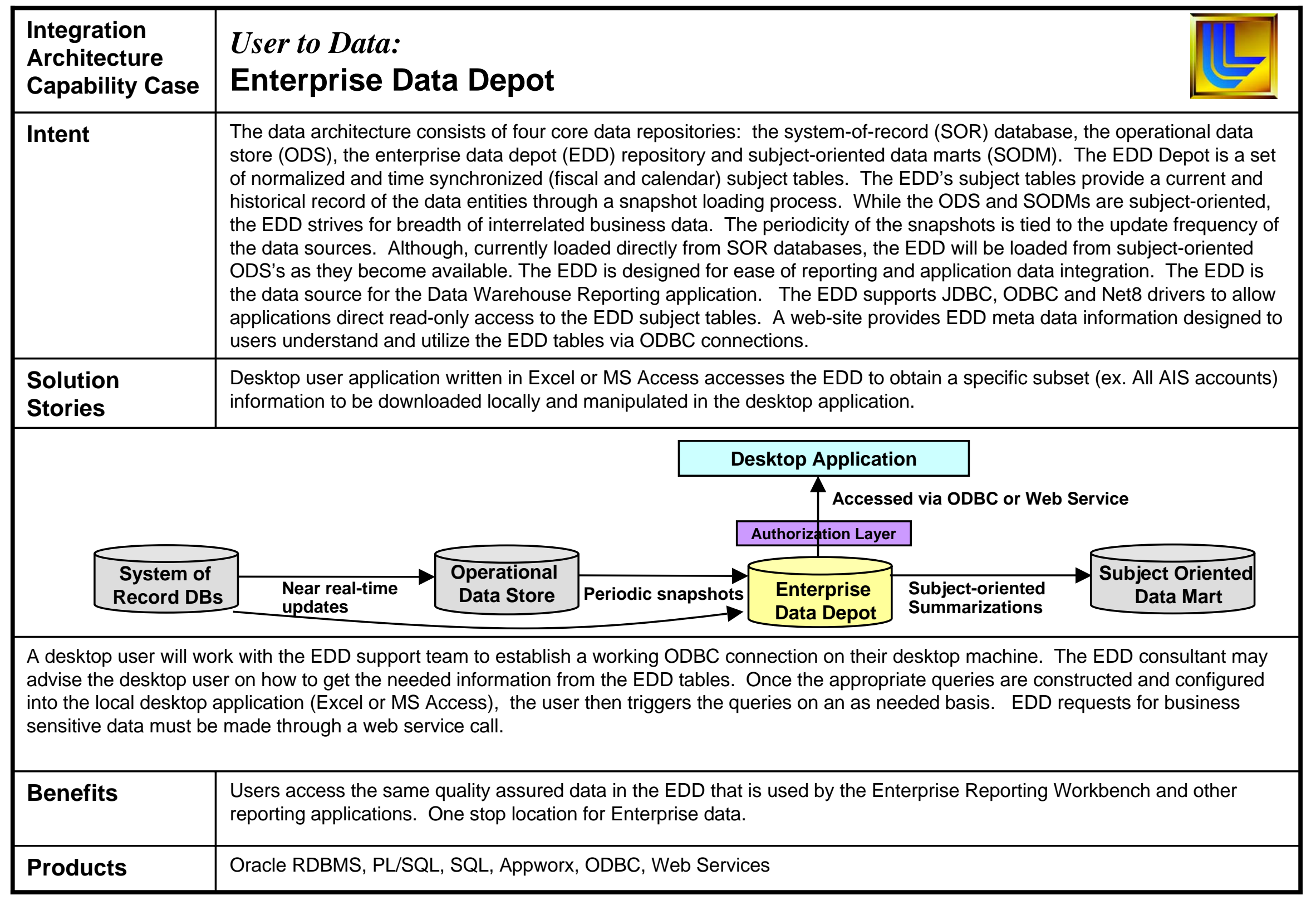

Note: Capability case diagrams reflect logical, not physical relationships. 


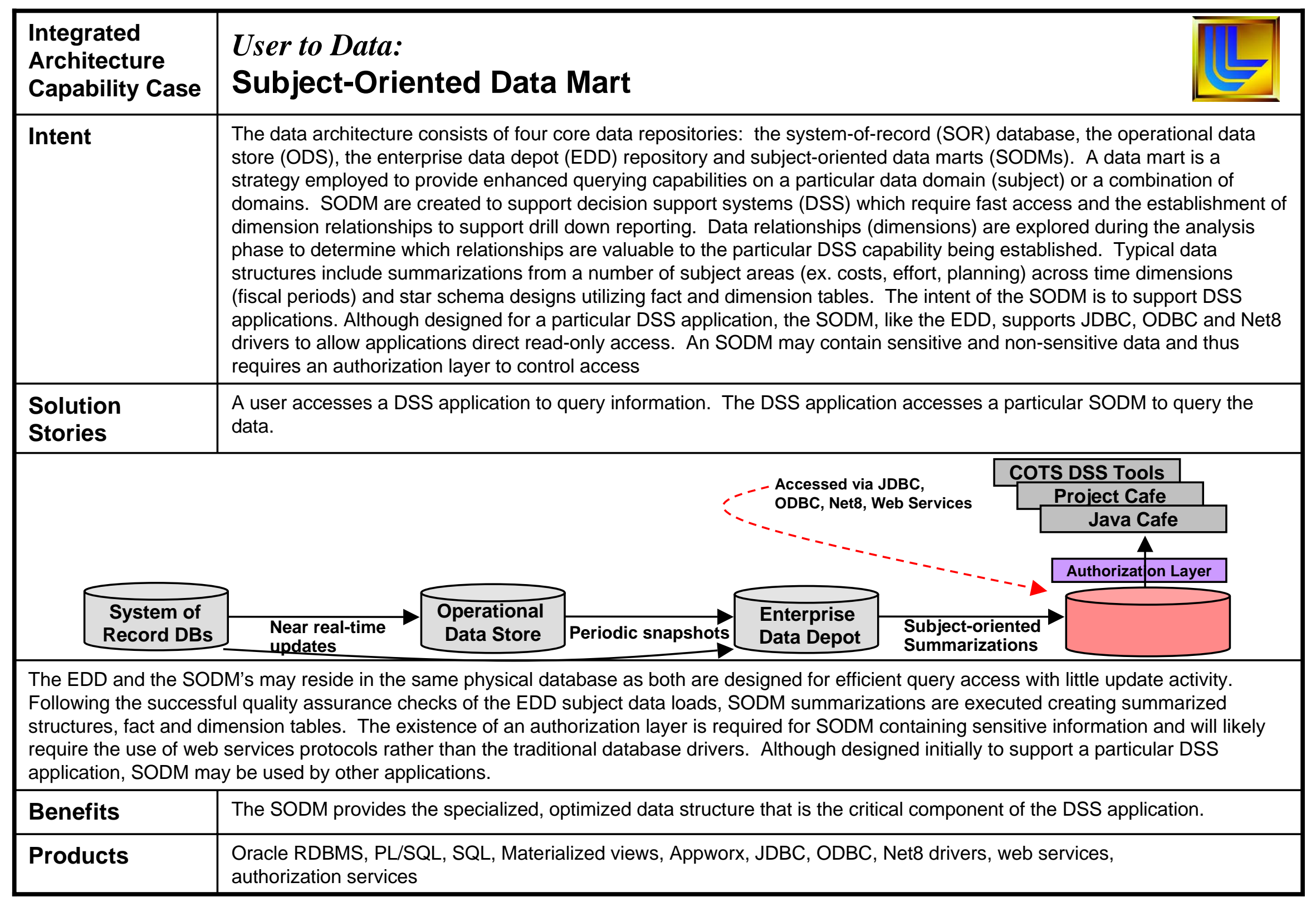

Note: Capability case diagrams reflect logical, not physical relationships. 


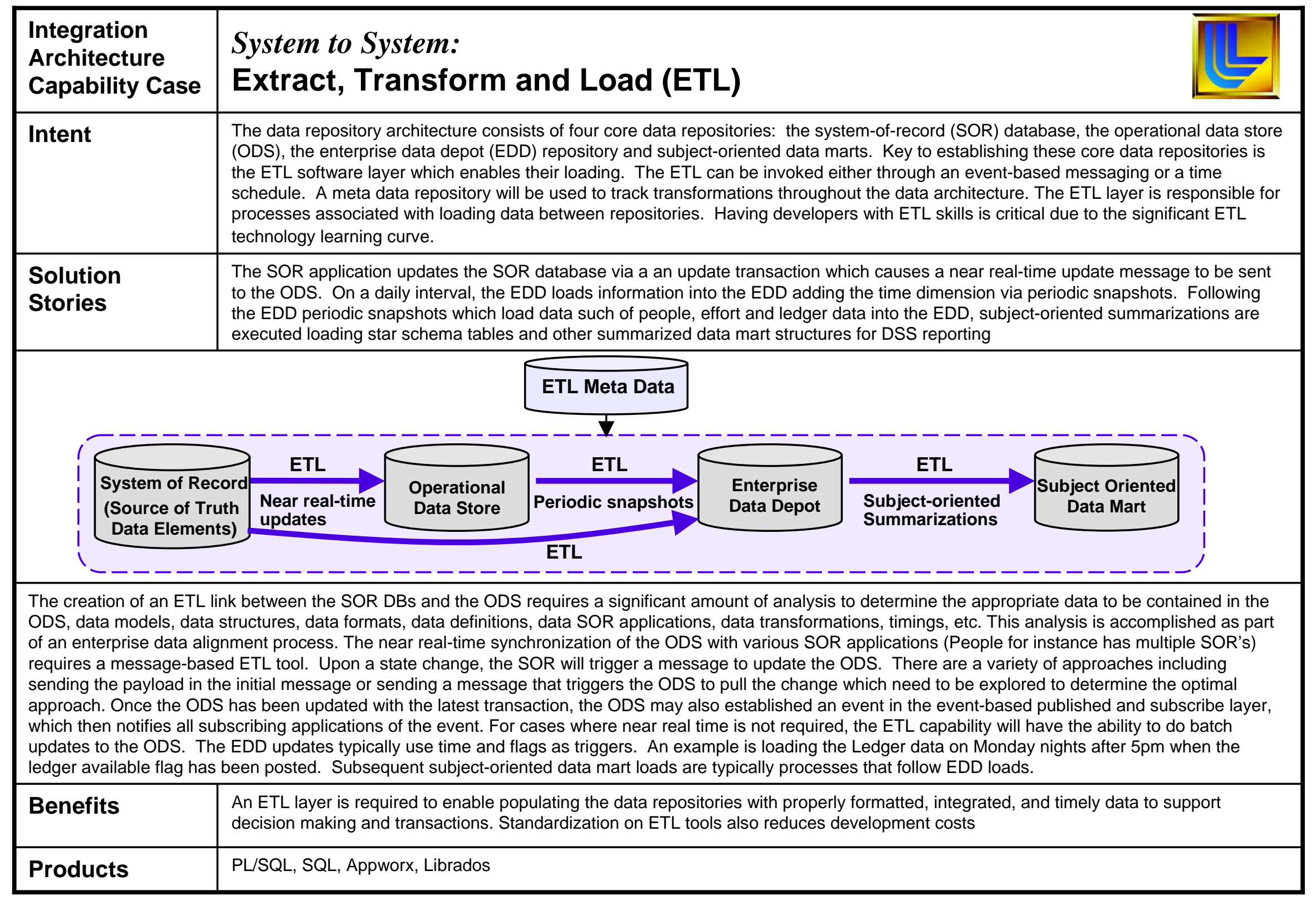

Note: Capability case diagrams reflect logical, not physical relationships. 


\section{Process Tier Capability Cases}

\begin{tabular}{|c|c|c|c|c|c|c|c|}
\hline & \multicolumn{5}{|c|}{ Business Architecture Pattern } & \multirow{2}{*}{$\begin{array}{c}\text { Foundational } \\
\text { Capabilities }\end{array}$} \\
\hline & & \begin{tabular}{|c} 
User to Business \\
(Transactional)
\end{tabular} & $\begin{array}{c}\text { User to Data } \\
\text { (Analytical) }\end{array}$ & $\begin{array}{l}\text { Bus. to Bus. } \\
\text { (Sys. to Sys.) }\end{array}$ & $\begin{array}{l}\begin{array}{l}\text { User to User } \\
\text { (Interaction) }\end{array} \\
\end{array}$ & $\begin{array}{l}\text { Org. to User } \\
\text { (Informational) }\end{array}$ & \\
\hline \multicolumn{2}{|c|}{$\begin{array}{c}\text { Presentation } \\
\text { Tier }\end{array}$} & & & & & & \\
\hline \multirow{2}{*}{ 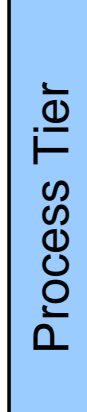 } & $\begin{array}{c}\text { Federated } \\
\text { (loose coupling) }\end{array}$ & $\begin{array}{l}\text { - Business Process } \\
\text { Orchestration } \\
\text { Workflow }\end{array}$ & $\begin{array}{l}\text { Enterprise Rptg. } \\
\text { Decision Support } \\
\text { (static \& dynamic) }\end{array}$ & $\begin{array}{l}\text { - Synchronous } \\
\text { Request \& Reply } \\
\text { - Asynchronous } \\
\text { Publish \& } \\
\text { Subscribe }\end{array}$ & \multirow{2}{*}{$\begin{array}{l}\text { - Email } \\
\text {. Calendaring } \\
\text { Document Mgt } \\
\text { D Distributed } \\
\text { Authoring and } \\
\text { Versioning } \\
\text { - Instant } \\
\text { Messaging } \\
\text { - On-line meeting } \\
\text { environments }\end{array}$} & \multirow[t]{2}{*}{$\begin{array}{l}\text { - Messaging } \\
\text { Facility }\end{array}$} & \\
\hline & $\begin{array}{c}\text { Monolithic } \\
\text { Homogenous } \\
\text { (tight coupling) }\end{array}$ & - Proprietary & $\begin{array}{l}\text { - Application Specific } \\
\text { Reporting }\end{array}$ & $\begin{array}{l}\text { - Inter-process } \\
\text { Communication } \\
\text { - File Transfer }\end{array}$ & & & \\
\hline \multirow{2}{*}{ 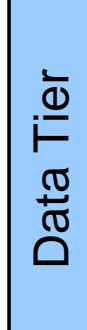 } & $\begin{array}{l}\text { Structured } \\
\text { (data) }\end{array}$ & & & & & & \\
\hline & $\begin{array}{l}\text { Unstructured } \\
\text { (content) }\end{array}$ & & & & & & \\
\hline
\end{tabular}




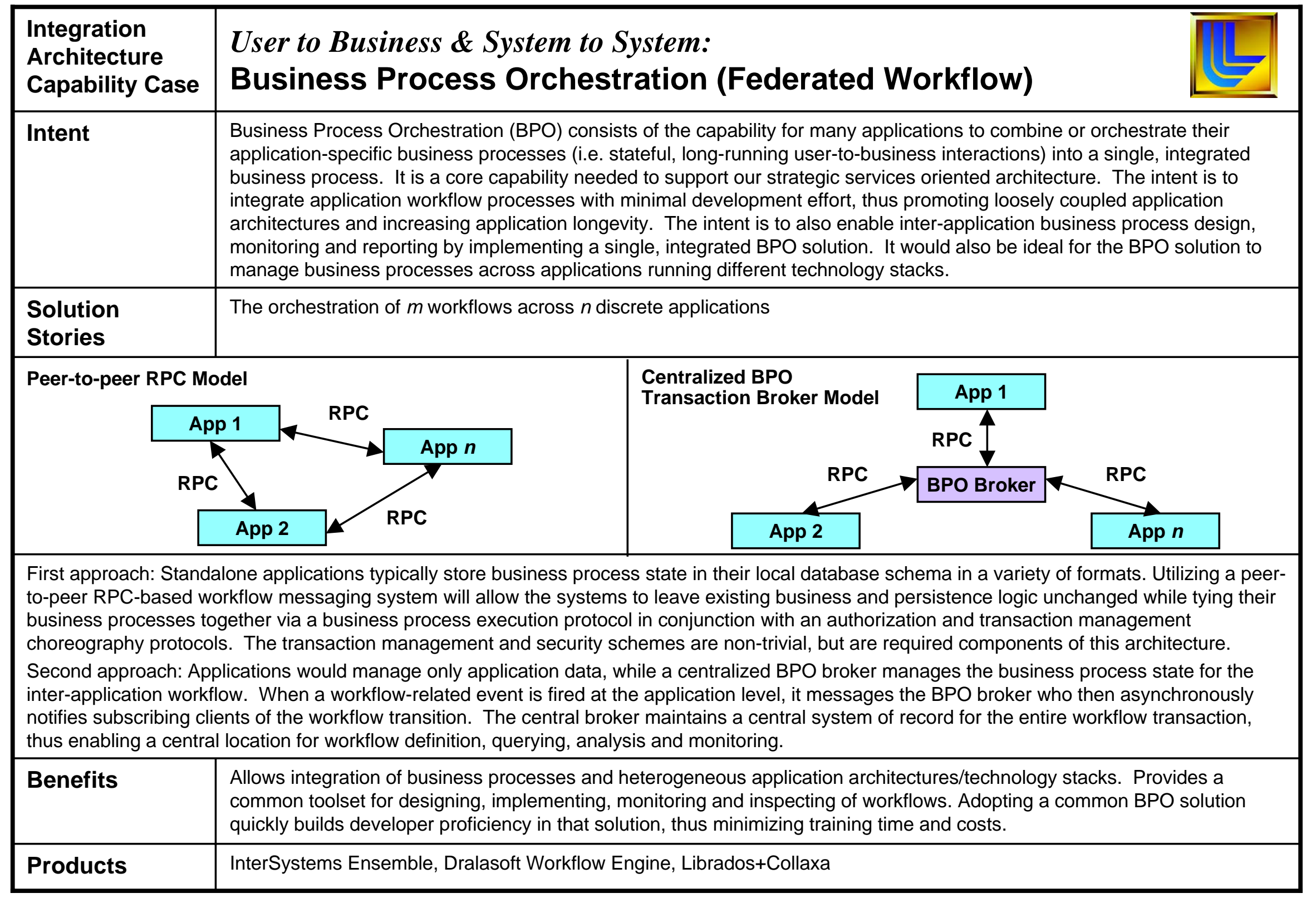

Note: Capability case diagrams reflect logical, not physical relationships. 


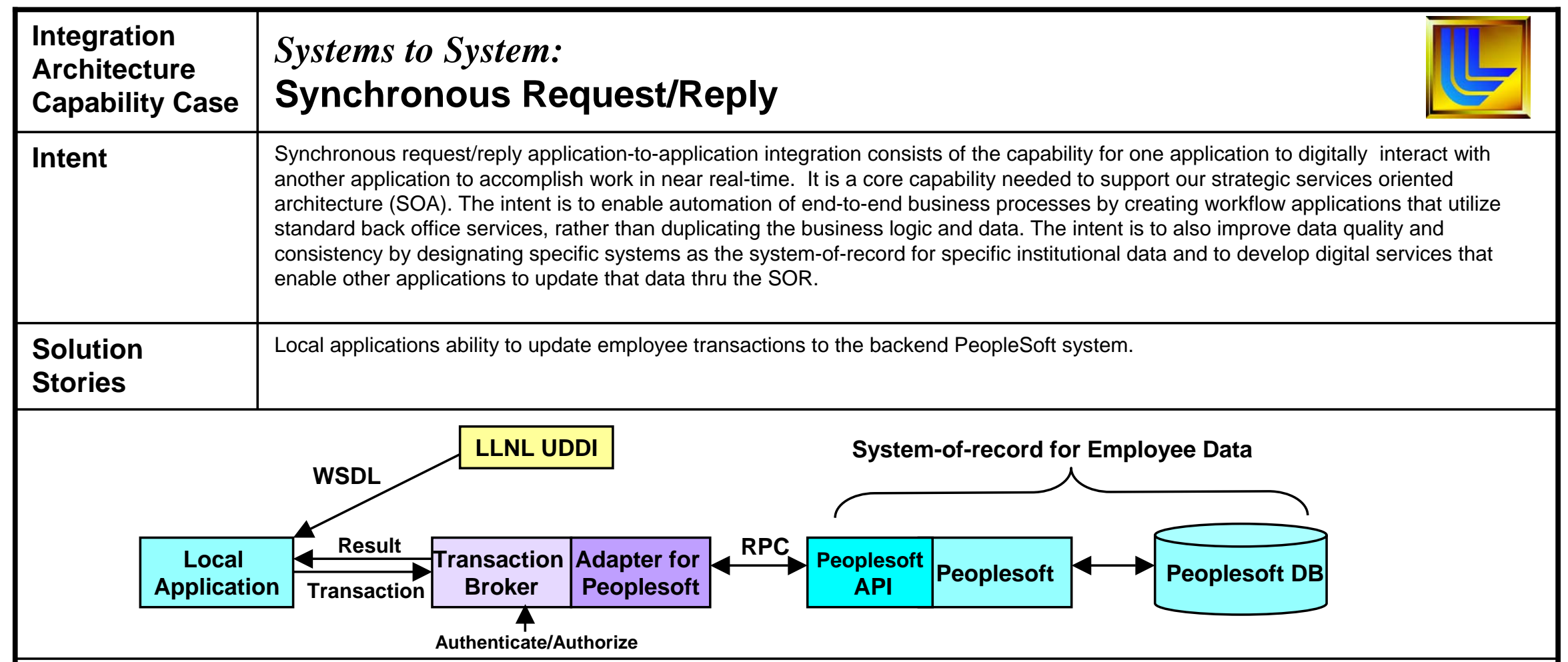

A local application would like to update an employee's address in the institutional Peoplesoft system. The application checks with the LLNL UDDI repository to obtain the WSDL description of the employee address update service, including where the service is located and how to invoke it (parameters, method names, etc.). It then makes a synchronous call (XML/SOAP/HTTPS) to the service which is managed by a transaction broker, passing it the XML payload for the transaction, and then blocks and waits for a response. The transaction broker invokes its Peoplesoft adapter to establish an RPC based synchronous connection to the Peoplesoft API for updating addresses and sends it the relevant transaction data. The process then blocks while waiting for a reply. The Peoplesoft application edit checks the transaction data, updates the database, and notifies the adapter that the transaction was successful. The adapter communicates the successful completion of the transaction back to the local app.

Desired attributes of this capability include the ability to dynamically discover what services are available, where they are located, and how to interface with them (eg parameters, methods, authentication, authorization, etc.); transaction management services that insure integrity and performance; logging; metrics; transformation services; loose coupling; and the availability of a core set of institutional business services.

\section{\begin{tabular}{l|l} 
Benefits & Programming and architectural flexibility and efficiency. Use of available services without required prior knowledge of what they are and
\end{tabular} how they work. Dynamic composition of business processes to reflect specific requirements.}

Products

Librados, Oracle Integration Suite, J2EE/JCA/JMS Open Source Integration Suite. 


\begin{tabular}{|c|c|}
\hline $\begin{array}{l}\text { Integration } \\
\text { Architecture } \\
\text { Capability Case }\end{array}$ & $\begin{array}{l}\text { System to System: } \\
\text { Asynchronous Publish/Subscribe }\end{array}$ \\
\hline Intent & $\begin{array}{l}\text { Asynchronous publish/subscribe application-to-application integration consists of the capability for an application to digitally subscribe to } \\
\text { a service to be notified of specific events in near real-time. It is a core capability needed to support our strategic services oriented } \\
\text { architecture. The primary intent of this capability is to enable applications to be notified in near real time of events that they need to } \\
\text { respond to rapidly. }\end{array}$ \\
\hline $\begin{array}{l}\text { Solution } \\
\text { Stories }\end{array}$ & $\begin{array}{l}\text { The CSTI AAMS system creates OUNs and PACs for users so they can access institutional applications. Currently there is at least a } 24 \\
\text { hour lag time from when an employee gets hired to when AAMS creates their OUN and PAC. AAMS would like to be notified in near real } \\
\text { time when a new employee is hired so they can create the OUN and PAC for the employee and enable the employee to access } \\
\text { institutional applications like email and calendaring as soon as possible. }\end{array}$ \\
\hline \multirow{2}{*}{ AAMS } & $\begin{array}{ll} & \text { Publish New } \\
\text { en Employee } & \text { Employee }\end{array}$ \\
\hline & $\underset{\text { Scribe to New }}{\longrightarrow}$ Service \\
\hline \multirow{3}{*}{\multicolumn{2}{|c|}{$\begin{array}{l}\text { AAMS would like to be notified when a new employee starts at the Lab. AAMS makes an asynchronous call to the Java Messaging Service (JMS) and subscribes to } \\
\text { the new employee event. The Peoplesoft application publishes all new employee events asynchronously to the JMS queue with the appropriate new employee } \\
\text { event topic identifier. When the JMS service receives the new employee event, it notifies the AAMS application of the event and passes it the new employee } \\
\text { message. The AAMS application sends back a reply that the message was received. The JMS service then deletes the message from the queue. } \\
\text { Prior to the deployment of this integration path, agreement has to be reached between the IT providers on the content, structure, and meaning of the new employee } \\
\text { event message (probably an XML document). Also, the integration infrastructure has to have the capability for authenticating and authorizing the AAMS application } \\
\text { to insure it has the authority to see the new employee message data. Will also require audit trails and logs. } \\
\text { Desired attributes of this capability include the ability to discover what events are available, where they are located, and how to interface with them (eg parameters, } \\
\text { methods, authentication, authorization, etc.); transaction management services that insure integrity and performance; logging; metrics; transformation services; } \\
\text { loose coupling; and the availability of a core set of institutional business event notifications. }\end{array}$}} \\
\hline & \\
\hline & \\
\hline Benefits & $\begin{array}{l}\text { Programming and architectural flexibility and efficiency. Use of available services without required prior knowledge of what they are and } \\
\text { how they work. Dynamic composition of business processes to reflect specific requirements. }\end{array}$ \\
\hline Products & Librados, Oracle Integration Suite, J2EE/JCA/JMS Open Source Integration Suite. \\
\hline
\end{tabular}

Note: Capability case diagrams reflect logical, not physical relationships.

As of $2 / 27 / 2004$ 


\section{Integration \\ Architecture Capability Case \\ User to Data: \\ Integrated Reporting Framework Overview}

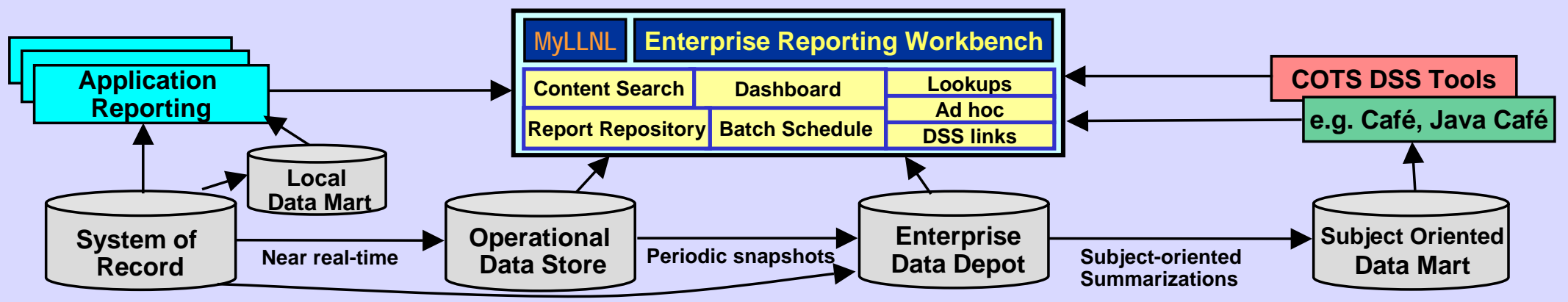

\section{Enterprise Reporting Workbench}

\section{Application Reporting}

Usability:

- Target: Process participants

- Requires domain knowledge

- Learning curve varies

Source: System of record w/real-time access or localized data mart

Reporting types:

- Optimized for real-time process-specific reporting

- Pre-defined reports

- Workflow reporting

- Exception reports

- Real-time dashboard

- Batch or on-demand

- Web-based

\section{Analytical Reporting}

Usability:

- Target: General analyst roles and the enterprise user

- Requires domain knowledge

- "Zero" learning curve

Source: Near real-time ODS, periodic snapshot crossdomain data structures, integrated dimension data

Reporting types:

- Optimized for periodic general reporting, simple ad hoc reporting \& lookups

- Pre-defined reports

- Snap shot dashboard

- Batch or on-demand

- Web-based, graphical, tight Excel integration

\section{Static Decision Support}

Usability:

- Target: Specific analyst roles

- Requires domain knowledge

- "Zero" learning curve

Source: Summarized data mart optimized for specific use

Reporting types:

- Optimized for specific analyst communities

(e.g. RAs, Project Mgt., etc.)

- Pre-defined reports

- Pre-defined drill paths

- Web-based, graphical, tight Excel integration

\section{Dynamic Decision Support}

Usability:

- Target: Highly specialized analysts

- Requires expert-level domain knowledge

- Extensive learning curve

Source: Star schema or dimensional Data Mart optimized for specific use

Reporting types:

- Optimized for complex ad hoc analysis

- Dynamic drill paths

- Slice and dice

- Sophisticated GUI, graphical, tight Excel integration 


\begin{tabular}{|c|c|}
\hline $\begin{array}{l}\text { Integration } \\
\text { Architecture } \\
\text { Capability Case }\end{array}$ & $\begin{array}{l}\text { User to Data: } \\
\text { Enterprise Reporting Workbench }\end{array}$ \\
\hline Intent & $\begin{array}{l}\text { The Enterprise Reporting Workbench (ERW) provides the user with a single interface to access enterprise reporting capabilities. The } \\
\text { ERW utilizes the MyLLNL interface to deliver web-based reporting capabilities, dashboard controls, content search, report scheduling and } \\
\text { distribution, report repository and links to community-based DSS applications. The ERW provides a common framework for report } \\
\text { publishing which allows developers of DSS reports to plug these reports into the scheduling and distribution and report repository } \\
\text { functionality. ERW is designed to be report writer agnostic. Lookups will utilize the operational data store (ODS) databases where } \\
\text { available. The user will be able to select among a number of subject-oriented dash board reports. Users can select links which will direct } \\
\text { them under auspices of single sign-on to the select DSS application. All reports that have been run, are available for } \\
\text { viewing/downloading from the Report Repository. The users will be able to view the data availability status of all data domains in the } \\
\text { ODS, Electronic Data Depot (EDD) and subject-oriented data marts (SODM). }\end{array}$ \\
\hline \multirow[t]{5}{*}{$\begin{array}{l}\text { Solution } \\
\text { Stories }\end{array}$} & $\begin{array}{l}\text { User has an enterprise reporting need and accesses the Enterprise Reporting Workbench as tab on the MyLLNL interface. Upon review } \\
\text { of their dashboard, the user selects the appropriate reporting option to understand the dashboard alarm. User sets up a series of } \\
\text { scheduled reports to track information following the update frequency (daily, weekly) of the data. }\end{array}$ \\
\hline & MyLLNL - Enterprise Reporting Workbench \\
\hline & Dashboard Content Search \\
\hline & \begin{tabular}{|l|l|l} 
Data availability & DSS links \\
\end{tabular} \\
\hline & 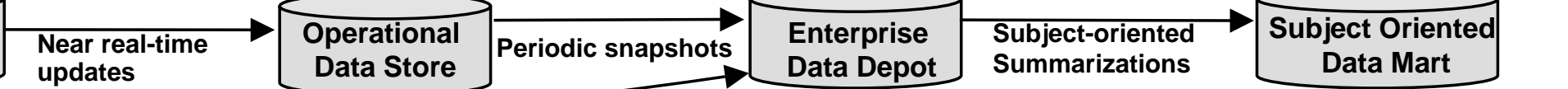 \\
\hline \multicolumn{2}{|c|}{$\begin{array}{l}\text { Users access the Enterprise Reporting Workbench via the MyLLNL interface and obtains access to a wide variety of enterprise reporting services. Based upon the } \\
\text { service selected the user may be transparently redirected to a DSS interface using single sign-on. Once in the DSS application, the user conducts drill down } \\
\text { analysis within a specific subject area. If the user selects a lookup, the ERW will access the appropriate subject ODS or EDD table if an ODS does not exist for this } \\
\text { subject. The current Data Warehouse reports, will be available for execution and scheduling. These reports run off the current EDD tables. Any report that has } \\
\text { been executed by a user is available to that user in their report repository sandbox (contains reports they can view). Although not depicted for diagram simplicity, } \\
\text { sensitive data will be delivered utilizing the authorization layer. }\end{array}$} \\
\hline Benefits & $\begin{array}{l}\text { There are two primary benefits of the ERW. First, from the user perspective, there is a one-stop shop for enterprise reporting. From an } \\
\text { IT perspective, economies of scale can be achieved by leveraging common reporting strategies and frameworks. }\end{array}$ \\
\hline Products & Oracle 10G, Oracle Reports, Jasper Reports, Java (J2EE), COTS and In-house DSS \\
\hline
\end{tabular}

Note: Capability case diagrams reflect logical, not physical relationships.

As of $2 / 27 / 2004$ 


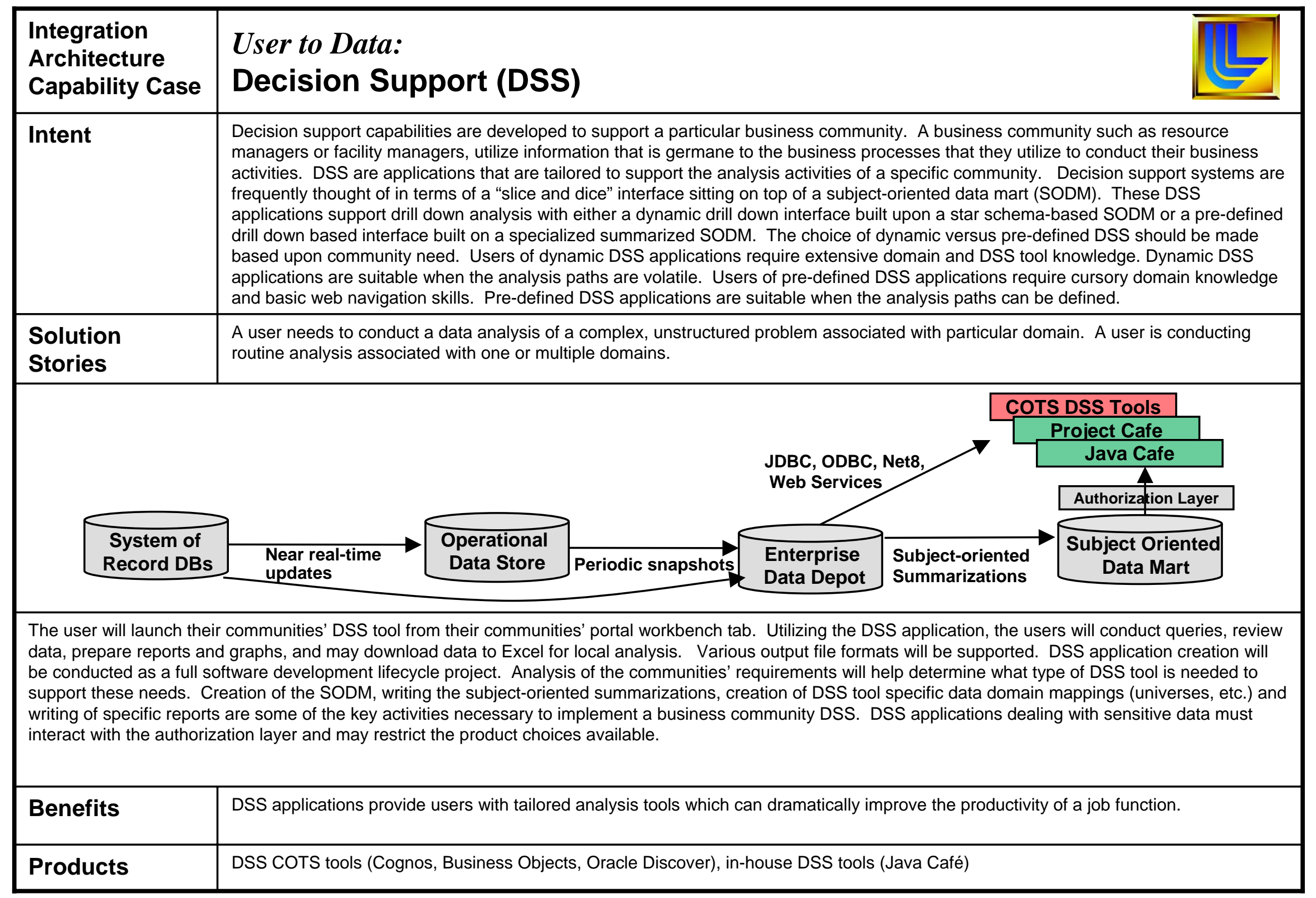

Note: Capability case diagrams reflect logical, not physical relationships.

As of $2 / 27 / 2004$ 


\begin{tabular}{|l|l|l|}
\hline $\begin{array}{l}\text { Integration } \\
\text { Architecture } \\
\text { Capability Case }\end{array}$ & $\begin{array}{l}\text { User to Business, User to User, User to Data: } \\
\text { Document Management }\end{array}$ \\
\hline Intent & \\
\hline $\begin{array}{l}\text { Solution } \\
\text { Stories }\end{array}$ & \\
\hline & \\
\hline
\end{tabular}

Note: Capability case diagrams reflect logical, not physical relationships. 


\section{Presentation Tier Capability Cases}

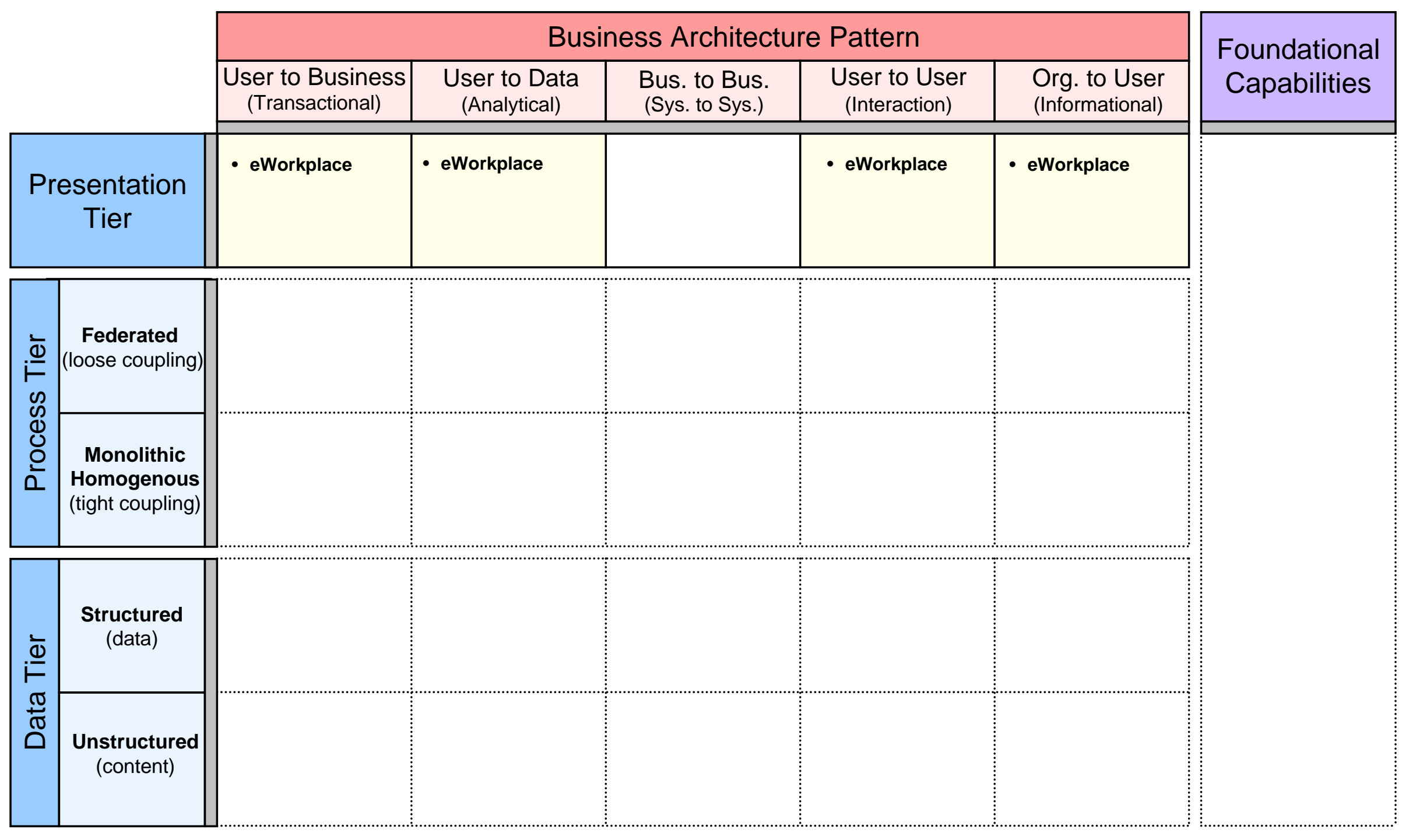




\begin{tabular}{|c|c|}
\hline $\begin{array}{l}\text { Integration } \\
\text { Architecture } \\
\text { Capability Case }\end{array}$ & $\begin{array}{l}\text { User to Business, User to Data, User to User and User to Organization: } \\
\text { eWorkplace }\end{array}$ \\
\hline Intent & $\begin{array}{l}\text { The eWorkplace delivers integrated static and dynamic content to a personal customizable web interface. Based on the end } \\
\text { user's profile, this integrated view uses Oracle Portal, the Portlet Repository, central authentication and authorization, } \\
\text { content management tools, and federated search and taxonomy tools to display static and dynamic content which includes } \\
\text { business and non-business specific operational transaction data, analytical data, web content, and the document repository. }\end{array}$ \\
\hline $\begin{array}{l}\text { Solution } \\
\text { Stories }\end{array}$ & $\begin{array}{l}\text { The end user accesses the eWorkplace, either unauthenticated or authenticated, to access all appropriate information and } \\
\text { electronic tools to accomplish their daily work tasks. }\end{array}$ \\
\hline & $\begin{array}{l}\text { ystems of Record } \\
\text { ODS, EDD }\end{array}$ \\
\hline BROWSER & $\begin{array}{c}\text { PORTAL } \\
\text { personalization } \\
\text { default views }\end{array}$ \\
\hline & $\begin{array}{l}\text { CONTENT } \\
\text { MANAGEMENT } \\
\text { meta data }\end{array}$ \\
\hline \multicolumn{2}{|c|}{$\begin{array}{l}\text { An unauthenticated user accesses the eWorkplace to view the default interface including federated search, taxonomy, utilities, application } \\
\text { interfaces, institutional workbenches, and static content. The user authenticates to the eWorkplace to view and interact with personalized content, } \\
\text { operational information, applications, and workbenches that are applicable to their role(s). Using advanced and integrated search tools, the user } \\
\text { retrieves content and inferred content that reflects application roles and responsibilities. The authenticated user customizes the presentation and } \\
\text { content of their eWorkplace. }\end{array}$} \\
\hline Benefits & $\begin{array}{l}\text { Improved user experience and efficiency due to the personalized, customized interface and federated search. Reduction in } \\
\text { training due to common look and feel. Ease of access to job-related information and applications through access to } \\
\text { integrated information and personalized content. Flexibility for reuse of portlets and portlet development methodology. }\end{array}$ \\
\hline Products & $\begin{array}{l}\text { Oracle Portal, OAS, 10G, Java/JSP/Servlets, Javascript, HTML, Verity, Taxonomy, collaboration tools, IE6, Mozilla, } \\
\text { Remedy, Livelink }\end{array}$ \\
\hline
\end{tabular}

Note: Capability case diagrams reflect logical, not physical relationships. 


\section{Foundational Capability Cases}

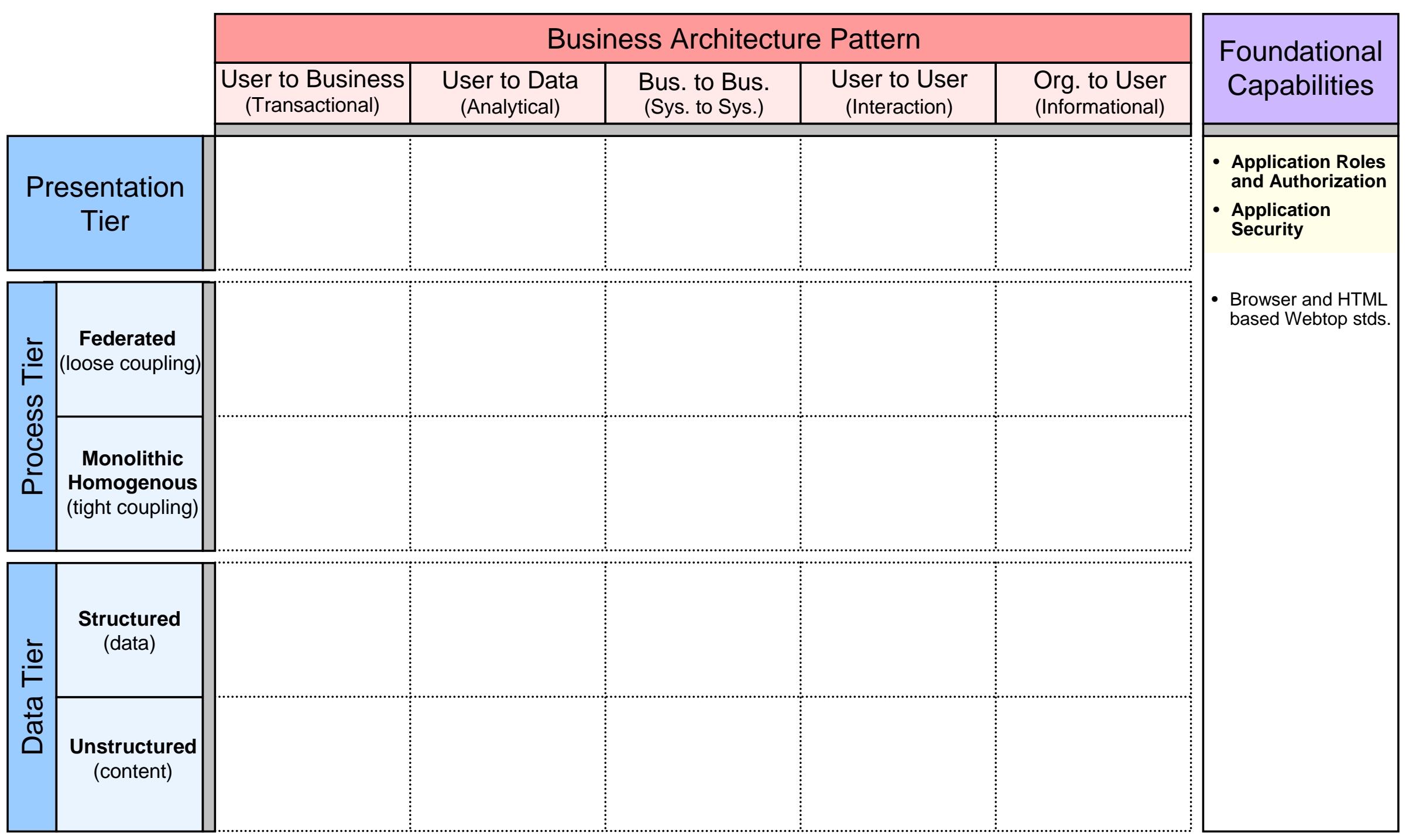




\begin{tabular}{|c|c|}
\hline $\begin{array}{l}\text { Integration } \\
\text { Architecture } \\
\text { Capability Case }\end{array}$ & $\begin{array}{l}\text { Foundational Capability: } \\
\text { Security Model for Heterogeneous System Integration }\end{array}$ \\
\hline Intent & $\begin{array}{l}\text { Synchronous and asynchronous request/reply application-to-application integration in which sensitive data is accessed or } \\
\text { transformed requires the capability for one application to securely interact with another application. It is a core capability } \\
\text { needed to support our strategic services oriented architecture. The intent is to centralize a trust mechanism such that } \\
\text { services can be invoked by a restricted set of users and systems in an auditable way. }\end{array}$ \\
\hline $\begin{array}{l}\text { Solution } \\
\text { Stories }\end{array}$ & $\begin{array}{l}\text { Applications have the ability to securely identify themselves so that system interactions are auditable and able to be } \\
\text { restricted. }\end{array}$ \\
\hline & cal App \\
\hline \multicolumn{2}{|c|}{$\begin{array}{l}\text { A local application would like to update an employee's address in an institutional system. The application sends a request to the institutional trust } \\
\text { server asking for a token to include or encrypt its message to the institutional system. The institutional trust server then issues a challenge to the } \\
\text { local application to prove its identity. Upon completion of a successful challenge, the local app receives a token from the trust authority. The } \\
\text { updated message is then sent to the institutional service with the token. The institutional service then uses the token to query the trust server as to } \\
\text { the authenticity of the message. The trust authority responds with a message indicating the authenticity of the token. }\end{array}$} \\
\hline \multicolumn{2}{|c|}{$\begin{array}{l}\text { With a non-repudiation mechanism in place, a user identifier/credential can be sent along with the message indicating which user is invoking the } \\
\text { service call. With an institutional roles store, the institutional service can query such a store to determine if that specific user has the ability to } \\
\text { invoke the institutional service in question. In a less fine grained model, a system identifier can be sent with the message and a institutional } \\
\text { systems definition can be queried to determine authorization. }\end{array}$} \\
\hline Benefits & $\begin{array}{l}\text { Ability to restrict access to sensitive services based upon user authorization levels. Potential for the aggregation of access } \\
\text { control levels to a centralized mechanism. }\end{array}$ \\
\hline Products & SAML, Digital Signatures, Java Cryptography API \\
\hline
\end{tabular}

Note: Capability case diagrams reflect logical, not physical relationships. 


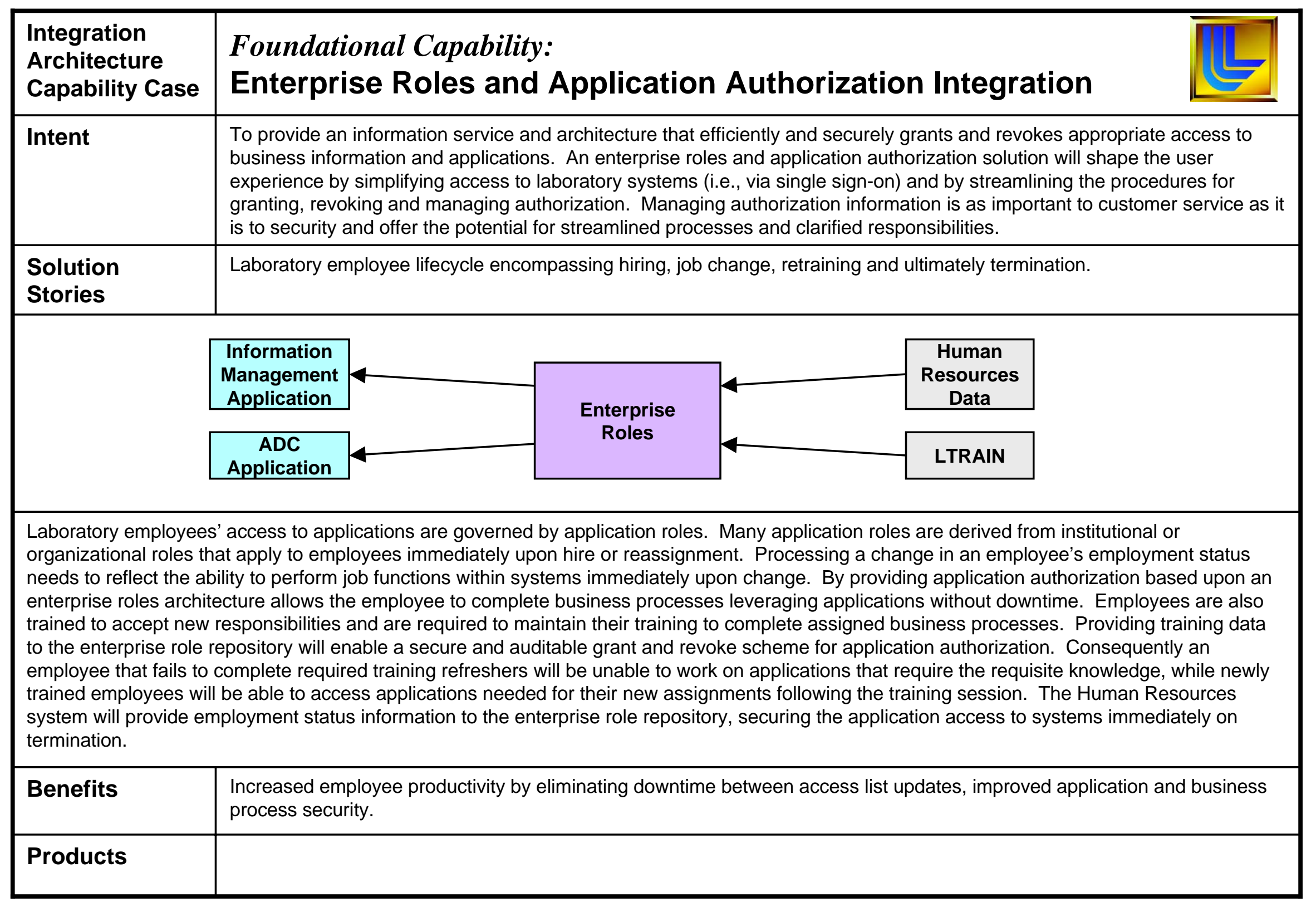

Note: Capability case diagrams reflect logical, not physical relationships. 


\begin{tabular}{|l|l|}
\hline $\begin{array}{l}\text { Integration } \\
\text { Architecture } \\
\text { Capability Case }\end{array}$ & \\
\hline Intent & \\
\hline $\begin{array}{l}\text { Solution } \\
\text { Stories }\end{array}$ & \\
\hline
\end{tabular}

\section{Benefits}

\section{Products}

Note: Capability case diagrams reflect logical, not physical relationships. 